\title{
Determination of Sampling Unit Size for Cultivation Area Survey using Remote Sensing Technology
}

\author{
Jinwoo Park ${ }^{1}$. Gieun Shin ${ }^{2}$. Sukhoon Lee ${ }^{3} \cdot$ Jongseok Byun $^{4}$ \\ ${ }^{1}$ Department of Applied Statistics, University of Suwon \\ ${ }^{2}$ Department of Information and Statistics, Chungnam National University \\ ${ }^{3}$ Department of Information and Statistics, Chungnam National University \\ ${ }^{4}$ Department of Applied Statistics, Hanshin University
}

(Received July 23, 2012; Revised September 10, 2012; Accepted September 20, 2012)

\begin{abstract}
The successful launch of Arirang satellites allow the acquisition of high resolution satellite imagery of Korean territory and enables the transition from the conventional cultivation area survey method to new image based methods adopted in advanced nations. In this study, we suggested reasonable sizes of the primary sampling unit and the secondary sampling unit for the satellite imagery based sampling design in 8 provinces preselected for this research. The PSU size was determined mainly in consideration of intracorrelation that shows the degree of homogeneity within each cluster and the efficiency of the image process. For the SSU size, we considered the relative standard error and the differences between the land cover maps produced by the Ministry of Environment and the satellite imagery processed by the National Statistical Office.
\end{abstract}

Keywords: Land cover map, remote sensing, satellite imagery, sampling unit, cluster, intracluster correlation coefficient, relative standard error.

\section{1. 서론}

통계청에서 실시하는 농업면적조사(경지면적 및 작물재배면적 조사)는 경지면적을 파악하여 토지자원 의 확보와 이용, 작물생산계획 수립 등 주요 농업정책수행에 필요한 기초자료를 얻는 것을 목적으로 하 는 국가승인통계이다 (National Agricultural Products Quality, 2007). 먼저 토지대장과 지적도를 이 용하여 전국의 경지를 약 $2 \mathrm{ha}$ 크기의 추출단위인 조사구로 나누어 추출틀을 구성하였다. 다음에 표본설 계를 통해 약 25,000 개의 표본 조사구를 추출한 후, 조사원이 현장에 나가 표본 조사구를 실측하는 방법 으로 경지면적을 추정한다. 이러한 실측조사는 인력과 비용이 많이 들고 비표본오차 발생 가능성이 높 은 것으로 알려져 있다.

미국, 유럽연합 등에서는 일찍이 농업조사를 위해 인공위성 영상을 활용하는 원격탐사기술(Remote Sensing Technology)을 도입하여 사용해오고 있다. 미국 NASS(National Agricultural Statistics Service)에서는 농업조사를 위한 추출틀로써 지역추출틀(area frame)을 사용하는데, 인공위성 영상을 활

\footnotetext{
${ }^{1}$ Corresponding author: Department of Applied Statistics, University of Suwon, Suwon 445-743, Korea. E-mail: jwpark@suwon.ac.kr
} 
용하여 지역추출틀을 작성하고 있다 (Davies, 2009). 한편, Eurostat에서도 LUCAS(Land Use/Cover Area frame statistical Survey)라는 이름으로 대규모 영상기반 농업면적조사를 실시하였다 (Gallego와 Delince, 2010).

우리나라에서는 2006 년 다목적실용위성인 아리랑 2 호의 성공적 발사를 계기로 저렴한 국산 고해상도 위 성영상의 활용이 가능해졌다. 환경부에서는 수질오염 총량제, 환경영향평가 등 주요 환경정책의 과학적 근거로 사용하기 위하여 토지피복도(Land Cover Map)를 1998년부터 제작하기 시작하였다 (Ministry of Environment, 2002). 토지피복도는 지표면의 현 상태를 있는 그대로 표현하기 때문에 대기, 수질뿐 만 아니라 토지의 현황 등을 예측할 수 있다. 따라서 토지피복도는 면적조사 표본설계를 위한 추출틀 자 료로 활용될 수 있다. 이에 따라 통계청은 원격탐사기술을 경지면적조사에 활용하는 연구를 실시한 바 있다 (Statistics Koreav, 2008, 2009). 전국 8개 시군 즉, 고령군, 김제시, 김포시, 부안군, 연기군, 용 인시, 진천군, 창원시의 환경부 피복도 자료에 영상처리를 하여 경지면적조사를 시범 실시하였다. 그 결 과 농업면적조사에 원격탐사기술을 접목시키는 것이 가능한 수준이라는 결론을 내린 바 있다.

농업면적조사와 같은 공간모집단에서 추출단위 분할에 대해서는 Matern (1980), Yfantis 등 (1987)의 연구 결과가 있는데, 대체로 정삼각형과 정사각형의 격자가 효율적인 것으로 알려져 있다. 추출단위의 모양에 대한 연구 결과는 있지만 추출단위의 크기에 대한 연구는 거의 소개되어 있지 않은 실정이다. 본 연구의 목적은 우리나라에서 인공위성 영상을 사용하여 경지총조사 표본설계를 실시하고자 할 때, 추출 단위 크기를 어떻게 정해야 하는지를 제시하는데 있다.

통계청에서는 2008년과 2009년에 걸친 시범사업을 통해 8개 시군 대상의 모집단 영상자료를 마련하 였다. 본 연구에서는 8 개 시범지역의 피복도와 영상자료를 사용하여 측정오류를 최소화하면서도 추출 단위의 특성, 인공위성 영상의 활용 비율 등을 종합적으로 고려한 추출단위의 크기를 결정하여 제시하 고자 한다. 본 연구에서는 층화 2단 집락추출법을 상정하여 적절한 1차추출단위(Primary Sampling Unit; PSU)와 2차추출단위(Secondary Sampling Unit; SSU)의 크기를 결정하고자 한다. 표본이론에 서 PSU가 SSU보다 표본오차에 보다 큰 영향을 미치는 것이 알려져 있다. 따라서 본 연구의 우선적인 관심사항은 효율적으로 PSU 크기를 정하는데 있다. 영상처리 작업의 편리를 도모하기 위해 1,2 차추출 단위의 형태는 모두 정사각형 모양으로 결정하였다.

\section{1 차추출단위의 크기 결정}

영상기반 표본조사를 위해 PSU를 정사각형 형태로 한다면 우리나라 추출틀은 개념적으로 나타내면 Figure 2.1의 (a) 형태를 띠게 된다. 이 그림에서 하나의 격자가 PSU가 되는데, PSU 격자들은 우리 나라의 모든 토지를 누락이나 중복 없이 나타내도록 해야 한다. Figure 2.1의 (b) 하나의 PSU만을 나 타내는 그림인데, 여기서 PSU의 크기를 어떻게 정해야 하는지를 결정해야 한다. 가령, 격자의 크기를 $1 \mathrm{Km} \times 1 \mathrm{Km}, 2 \mathrm{Km} \times 2 \mathrm{Km}, 3 \mathrm{Km} \times 3 \mathrm{Km}, 4 \mathrm{Km} \times 4 \mathrm{Km}, 5 \mathrm{Km} \times 5 \mathrm{Km}$ 중 어느 것으로 하는 것이 가장 효과 적일지를 선택해야 하는 것이다.

1 차 추출단위 크기의 결정을 위해서는 추출단위의 특성과 영상 활용비율 두 가지 요소를 고려한다. 1 차 추출단위는 일종의 집락(cluster)이라고 할 수 있다. 효율을 극대화시키기 위해서는 동일 집락에 속한 하위 추출단위들의 특성이 이질적(heterogeneous)이어야 한다. 따라서 다양한 1 차 추출단위 크기일 때 의 이질성의 정도를 파악해야 하는데, 이를 위해 본 연구에서는 집락의 이질성의 정도를 나타내기 위해 일반적으로 사용되는 급내상관계수(intracluster correlation coefficient)라는 측도를 사용하기로 한다. 아울러 이와 별도로 인공위성 영상의 활용비율이라는 현실적인 측면도 동시에 고려하게 된다. 


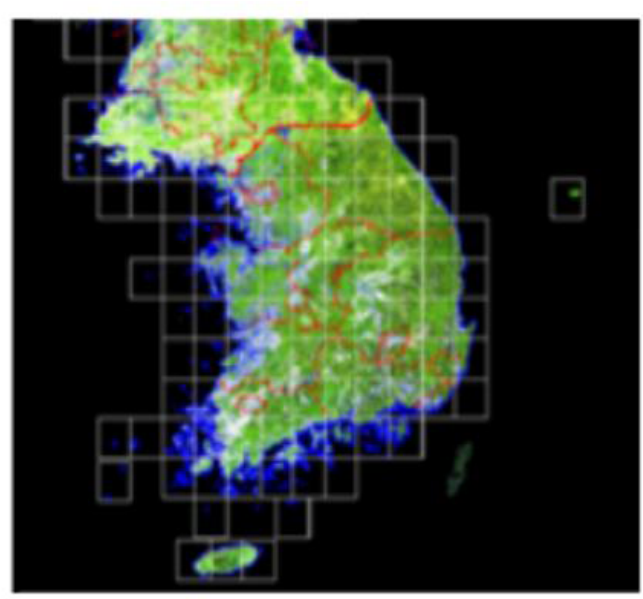

(a) Conceptual diagram of PSU

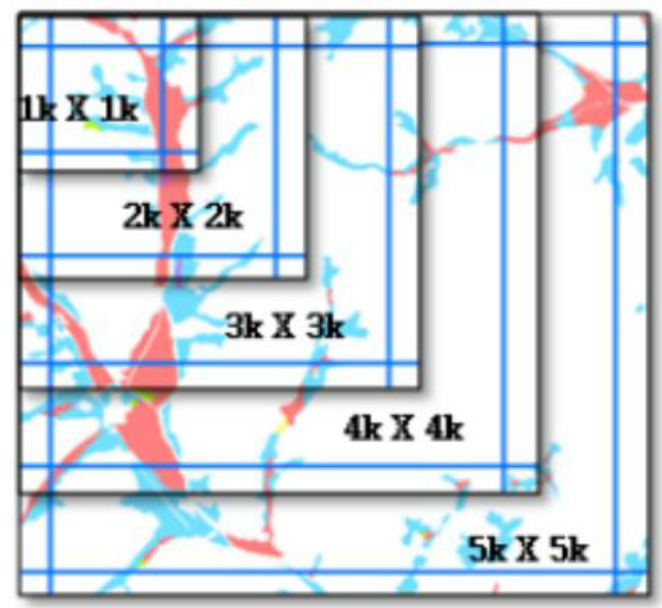

(b) Various sizes of PSUs

Figure 2.1. Concept of rectangular PSU

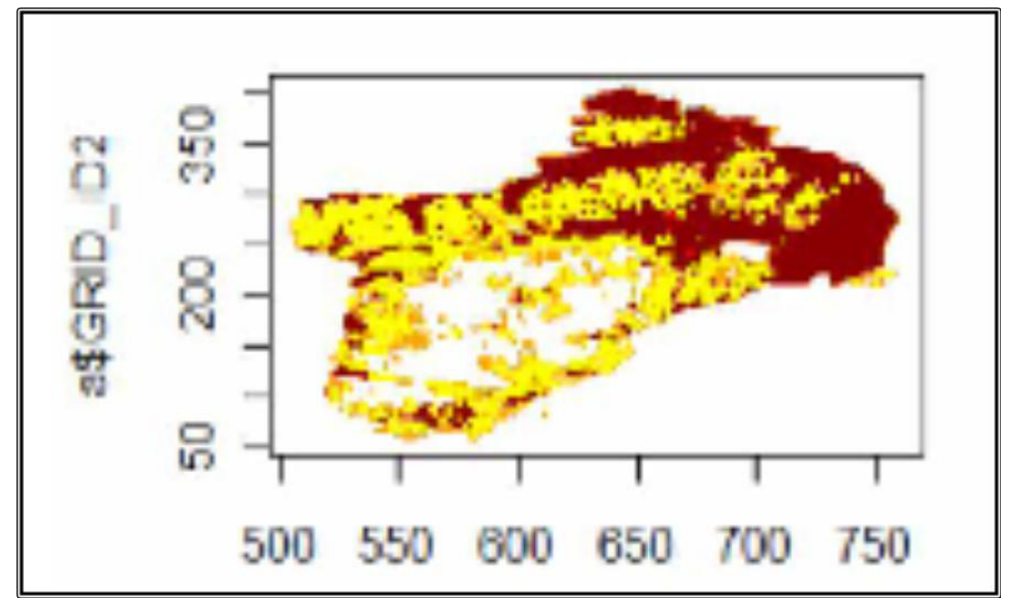

Figure 2.2. Paddy percentages of Buan-Gun

\section{1. 급내상관계수}

일반적으로 급내상관계수 $\left(\rho_{w}\right)$ 는 동일한 집락에 속하는 하위 추출단위들 사이의 동질성을 평가하는 척 도로 널리 사용된다. 모집단 급내상관계수는 동일한 집락에 속한 하위 추출단위들의 속성이 비슷할수록 커지며, 이질적일수록 작아진다. 이론적으로 $\rho_{w}$ 는 최소 $1 /(B-1)$ 에서 1 사이의 값을 가질 수 있는데, 여기서 $B$ 는 한 집락 내에서 추출되는 하위 추출단위의 수를 의미한다.

전북 부안군의 예를 살펴보자. Figure 2.2 는 부안군의 토지피복도를 기초로 논비율 정도를 표시한 것인 데, 엷은 색은 논비율이 높은 지역을, 짙은 색은 밭비율이 높은 지역을 나타낸다. 이 그림을 보면, 부안 군의 경우는 왼쪽 해안지역보다는 오른쪽 내륙지역에 논이 밀집되어 있음을 알 수 있다. 이러한 특성은 부안군에 대한 급내상관계수에 반영되어 나타날 것이다. 
Table 2.1. Intraclass correlation coefficients of various PSU sizes (Buan-Gun)

\begin{tabular}{|c|c|c|c|c|c|c|c|c|}
\hline & \multicolumn{8}{|c|}{ 급내상관계수 } \\
\hline & \multicolumn{4}{|c|}{ 논 } & \multicolumn{4}{|c|}{ 밭 } \\
\hline & \multicolumn{2}{|c|}{ 통계청 } & \multicolumn{2}{|c|}{ 피복도 } & \multicolumn{2}{|c|}{ 통계청 } & \multicolumn{2}{|c|}{ 피복도 } \\
\hline & 테두리 & $10 \%$ 초과 & 테두리 & $10 \%$ 초과 & 테두리 & $10 \%$ 초과 & 테두리 & $10 \%$ 초과 \\
\hline $1 \mathrm{Km} \times 1 \mathrm{Km}$ & 0.65 & 0.54 & 0.62 & 0.54 & 0.28 & 0.27 & 0.35 & 0.32 \\
\hline $2 \mathrm{Km} \times 2 \mathrm{Km}$ & 0.55 & 0.45 & 0.53 & 0.45 & 0.20 & 0.18 & 0.27 & 0.24 \\
\hline $3 \mathrm{Km} \times 3 \mathrm{Km}$ & 0.54 & 0.39 & 0.52 & 0.39 & 0.16 & 0.14 & 0.24 & 0.21 \\
\hline $4 \mathrm{Km} \times 4 \mathrm{Km}$ & 0.45 & 0.35 & 0.43 & 0.36 & 0.13 & 0.12 & 0.18 & 0.17 \\
\hline $5 \mathrm{Km} \times 5 \mathrm{Km}$ & 0.46 & 0.31 & 0.46 & 0.34 & 0.11 & 0.10 & 0.18 & 0.13 \\
\hline
\end{tabular}

부안군에 대한 피복도와 통계청 자료를 기초로 하여 논면적과 밭면적 각각에 대하여 $\rho_{w}$ 를 구한 결과가 Table 2.1 이다. 다른 시군과 경계를 같이하는 테두리셀 (edge cell)은 대부분 경지면적이 적어 전반적인 특성을 왜곡시킬 우려가 있으므로, 테두리셀을 제거한 나머지 셀을 가지고 $\rho_{w}$ 를 구하는 방안을 먼저 고 려하였다. 다음으로는 테두리 여부와 관계없이 전체적인 경지면적의 비율이 $10 \%$ 미만인 셀을 제거하는 방안을 고려하였다.

Table 2.1을 보면, 논면적이나 밭면적이나 모두 통계청이나 피복도 자료를 토대로 구한 $\rho_{w}$ 가 별 차이가 없으며, 테두리 셀을 제거한 것보다 경지면적 $10 \%$ 미만을 제거했을 때의 $\rho_{w}$ 가 대체로 작은 편이었다. 부안군의 $\rho_{w}$ 는 비교적 큰 편인데, 논면적인 경우 상대적으로 밭면적에 비해 더 크게 나타났다. 이것은 논의 경우가 상대적으로 밭에 비해 인접한 지역 내에 밀집되어 분포하는 경향이 커다는 것을 의미한다. 중요하게 고려해야 할 사항은 1 차 추출단위의 크기를 얼마로 할 때 $\rho_{w}$ 가 작아지는가 하는 점이다. 논과 밭 모두 격자의 크기를 크게 할수록 $\rho_{w}$ 가 작아지는 것을 관찰할 수 있다. 집락의 크기가 커질수록 동일 한 집락 내에 논과 밭이 혼재할 가능성이 커진다는 것을 생각하면 당연한 이치라고 할 수 있다. 전북 부 안군 이외의 나머지 7 개 시군의 결과도 부안군과 비슷한 양상을 보인다. 경지면적 $10 \%$ 미만을 제거한 경우, 논과 밭의 $\rho_{w}$ 를 효율적으로 줄이려면 $\mathrm{PSU}$ 격자의 크기를 $3 \mathrm{Km} \times 3 \mathrm{Km}, 4 \mathrm{Km} \times 4 \mathrm{Km}$ 로 하는 것이 바람직하다.

\section{2. 영상 활용비율}

1 차 추출단위의 크기를 결정하기 위해 중요하게 고려해야 할 또 다른 사항은 영상의 활용비율이다. 표 본 PSU가 추출되고 나면, 해당 PSU의 피복도 영상을 확보해야 한다. 하나의 피복도 영상의 통상적인 크기는 한 변의 길이가 $15 \mathrm{Km}$ 정도인데, 표본 PSU에 해당되는 피복도 영상 중에서 PSU 크기에 해당되 는 영상을 추출해야 한다. 그런데 PSU 격자가 커지게 되면 하나의 PSU 영상을 추출하기 위해 여러 개 의 피복도 영상을 결합해야 하는 상황이 빈번하게 생기게 된다. 제한된 여건 하에서 영상 수급을 원활하 게 하기 위해서는 가능한 한 최소한의 피복도 영상을 추출하는 것이 바람직하다. 이런 측면을 반영하기 위해 영상의 활용비율을 고려하고자 하는 것이다.

영상처리 전문가들이 산출한 격자크기별 영상 활용 비율이 Table 2.2 에 나와 있다. 이 표를 보면, 1 차 추출단위의 크기가 클수록 영상의 활용 비율이 낮아짐을 알 수 있다. 하나의 PSU 영상을 확보하기 위 해 피복도 영상을 사용하게 되는데, 정사각형의 격자가 커질수록 하나의 피복도 영상만으로 안 되고 여 러 개의 영상이 필요한 상황이 생기기 때문이다.

이상에서 살펴본 바와 같이, PSU의 이질성 측면에서 볼 때는 PSU가 커질수록 유리한 반면, 영상활용 비율 측면에서는 $\mathrm{PSU}$ 가 작을수록 효과적인 것으로 나타나 서로 상충되는 결과를 나타내고 있다. 영상 
Table 2.2. Image utilization percentages of various PSU sizes

\begin{tabular}{ccc}
\hline PSU 크기 & PSU수 & 비율 $(\%)$ \\
\hline $1 \mathrm{Km} \times 1 \mathrm{Km}$ & 128,216 & 61.4 \\
$2 \mathrm{Km} \times 2 \mathrm{Km}$ & 32,407 & 56.8 \\
$3 \mathrm{Km} \times 3 \mathrm{Km}$ & $\mathbf{1 4 , 5 6 7}$ & $\mathbf{5 0 . 1}$ \\
$4 \mathrm{Km} \times 4 \mathrm{Km}$ & 8,305 & 42.8 \\
$5 \mathrm{Km} \times 5 \mathrm{Km}$ & 5,361 & 35.3 \\
\hline
\end{tabular}

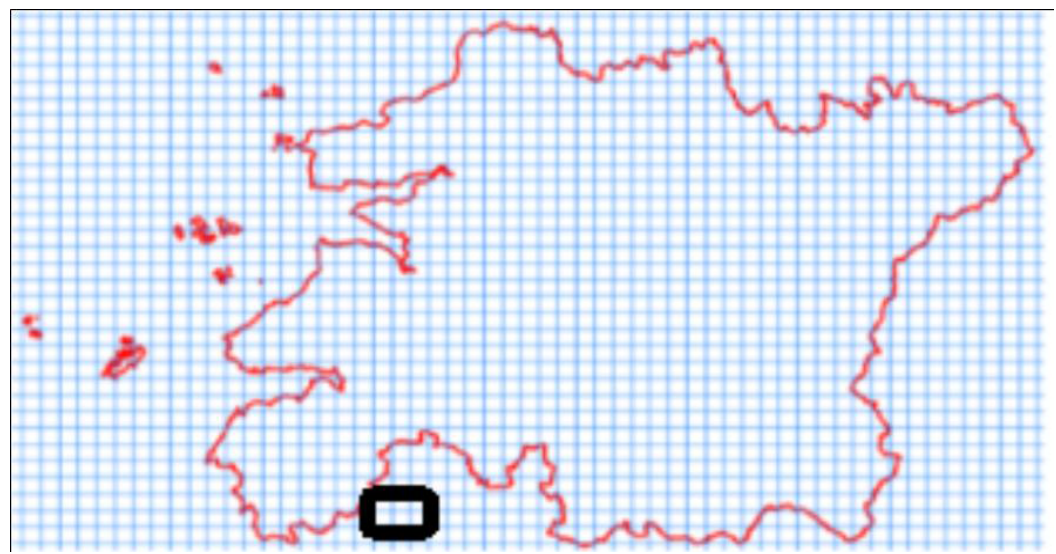

Figure 3.1. PSU grids of Jeollabuk-Do

활용 비율이 낮을 경우, 하나의 PSU 영상을 얻기 위해 여러 번의 위성사진을 촬영하는 것이 필요하게 되어 실용적인 면에서 불편함이 커진다. 따라서 합리적인 1 차 추출단위 크기 결정을 위해서는 통계적 효율과 영상활용 비율의 양쪽 측면에서 적절한 타협이 필요하다. 앞에서 통계적인 효율성만 고려했을 때에는 $3 \mathrm{Km} \times 3 \mathrm{Km}, 4 \mathrm{Km} \times 4 \mathrm{Km}$ 가 효과적이라고 한 바 있는데, 여기에 영상 활용 비율을 동시에 감안 한다면 $3 \mathrm{Km} \times 3 \mathrm{Km}$ 가 실용적으로 유용하다고 판단하였다.

\section{2 차추출단위의 크기 결정}

위에서 1 차추출단위 $(\mathrm{PSU})$ 크기를 $3 \mathrm{Km} \times 3 \mathrm{Km}$ 로 결정하였는데, 이는 실제 측정 혹은 원격탐사로 측정 하기에 큰 범위이므로 이를 다시 작은 정사각형의 격자로 분할하는 작업이 필요하다. 표본 PSU 내에서 다시 2 차 추출을 하기 위해서는 가장 효율적인 2 차 추출단위(SSU; secondary sampling unit)의 크기를 결정해야 한다. Figure 3.1 은 전라북도 지역의 PSU 격자를 나타낸 것이다. 한편, Figure 3.1의 왼쪽 아 래 부분에 굵은 선으로 표시한 부분을 확대한 그림이 Figure 3.2 인데, Figure 3.1 에 나타난 하나의 격자 가 Figure 3.2 에서는 굵은 선으로 표시된 큰 정사각형 격자이며 그 속에 있는 작은 격자 하나는 $\mathrm{SSU}$ 이 다.

표본 PSU에서 추출되는 $\mathrm{SSU}$ 에 대해서는 별도의 추가적인 영상처리 작업을 수행하여 면적 자료를 수 집하게 된다. 여기서도 PSU 크기 결정 때와 비슷하게 다양한 격자 크기를 비교하는데, $100 \mathrm{~m} \times 100 \mathrm{~m}$, $200 \mathrm{~m} \times 200 \mathrm{~m}, 400 \mathrm{~m} \times 400 \mathrm{~m}, 1000 \mathrm{~m} \times 1000 \mathrm{~m}$ 의 네 가지의 크기에 대해 고려하기로 한다. 최적의 SSU 크기 결정을 위해 먼저는 시군별 면적 추정량의 상대표준오차의 크기를 구하여 비교한 후, 다음으로는 격자 크기에 따른 시군별 피복도와 영상처리의 차이를 비교해보고자 한다. 


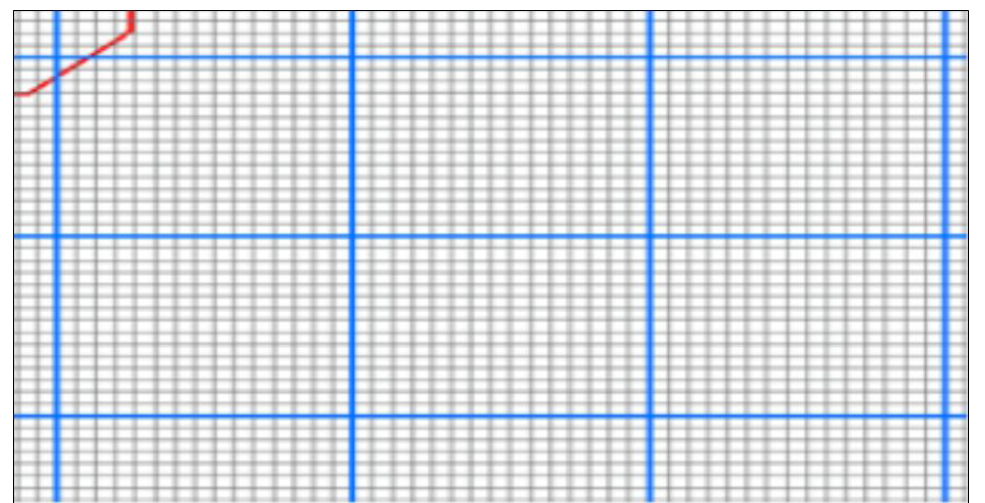

Figure 3.2. Segmentation of PSU to SSU

Table 3.1. Relative standard errors of estimated cultivation acreage for various SSU grid sizes

\begin{tabular}{cccccccccc}
\hline $\mathrm{SSU}$ & 고령 & 김제 & 김포 & 부안 & 연기 & 용인 & 진천 & 창원 \\
\hline $100 \mathrm{~m}$ & 1.26 & 1.07 & 1.07 & 0.96 & 1.22 & 1.24 & 1.14 & 1.73 \\
$200 \mathrm{~m}$ & 1.60 & 1.32 & 1.36 & 1.05 & 1.51 & 1.76 & 1.36 & 1.36 \\
$400 \mathrm{~m}$ & 1.95 & 1.53 & 1.47 & 1.49 & 1.49 & 1.56 & 1.50 & 1.73 \\
$1000 \mathrm{~m}$ & 1.33 & 1.82 & 1.57 & 1.41 & 1.75 & 2.02 & 1.57 & 1.42 \\
\hline
\end{tabular}

\section{(1) SSU 크기에 따른 상대표준오차 비교}

통계적으로 볼 때는 추정의 상대표준오차를 최소화시킬 수 있는 $\mathrm{SSU}$ 크기를 결정하는 것이 바람직하다. 8 개 시범지역에 대해서는 모집단 영상처리 자료의 활용이 가능하므로 시군별 추정량의 상대표준오차를 계산하여 비교하기로 한다.

다음의 Table 3.1에는 SSU 크기별로 경지면적 추정량에 대한 모집단 상대표준오차가 나와 있는데, 지 역에 따라 양상이 약간 차이가 나는 것을 관찰할 수 있다. 김제, 김포, 진천의 경우에는 격자의 크기 가 작을수록 상대표준오차가 작아지는 경향을 보이지만, 나머지 지역의 경우에는 뚜렷한 경향성이 드 러나지 않는다. 모든 지역에서 상대표준오차를 최소화시키는 $\mathrm{SSU}$ 크기가 동일하지는 않지만 대체로 $100 \mathrm{~m} \times 100 \mathrm{~m}, 200 \mathrm{~m} \times 200 \mathrm{~m}$ 가 효과적인 것으로 판단할 수 있다.

\section{(2) SSU 크기에 따른 피복도와 영상처리 자료의 비교}

다음으로 8 개 시범지역에 대한 자료를 이용하여 고려되는 2 차추출단위의 크기에 대한 피복도(환경부) 와 영상처리자료(통계청)의 논, 밭 면적의 차이를 비교하기로 한다. 2 차 추출단위인 정사각형 격자 내에 논, 밭, 과수 등 경지 전체에 대한 정보가 있지만, 경지 중 논과 밭의 비중이 가장 크므로 논면적과 밭면 적을 각각 비교한다.

먼저, 2 차 추출단위 크기 결정을 위해 8 개 시군마다 $100 \mathrm{~m}, 200 \mathrm{~m}, 400 \mathrm{~m}, 1000 \mathrm{~m}$ 의 정사각형 격자로 분 할한 후 피복도의 논면적 비율별로 논 면적을 계산해 비교하였다. Table 2.1-Table 3.2는 김포지역의 토지피복도와 원격탐사(통계청) 자료의 논면적 차이를 논비율 정도에 따라 비교한 결과를 나타낸다. 여 기서 차이\%는 다음과 같이 계산한 것이다.

$$
\text { 차이 } \%: \frac{\mid \text { 통계청 }- \text { 환경부 } \mid}{\text { 통계청 }} \times 100 \text {. }
$$


Table 3.2. Comparison of paddy acreage distribution for various SSU grid sizes (Gimpo-Si)

\begin{tabular}{|c|c|c|c|c|c|c|c|c|c|c|}
\hline 논 면적 & \multicolumn{5}{|c|}{$100 \times 100$} & \multicolumn{5}{|c|}{$200 \times 200$} \\
\hline \multirow{2}{*}{ 논 비율 } & \multirow{2}{*}{$N$} & \multicolumn{2}{|c|}{ 총계 } & \multirow{2}{*}{ 차이 } & \multirow{2}{*}{ 차이 $\%$} & \multirow{2}{*}{$N$} & \multicolumn{2}{|c|}{ 총계 } & \multirow{2}{*}{ 차이 } & \multirow{2}{*}{ 차이\% } \\
\hline & & 통계청 & 피복도 & & & & 통계청 & 피복도 & & \\
\hline $0 \%$ & 218 & 32.3 & 0.0 & 32.3 & 100.00 & 12 & 0.0 & 0.0 & 0.0 & 0.00 \\
\hline$-10 \%$ 이하 & 73 & 24.8 & 14.3 & 10.5 & 42.29 & 8 & 14.1 & 7.5 & 6.6 & 46.58 \\
\hline$-20 \%$ 이하 & 51 & 29.4 & 39.1 & -9.7 & -33.03 & 6 & 10.9 & 10.5 & 0.4 & 3.57 \\
\hline$-30 \%$ 이하 & 54 & 53.8 & 72.1 & -18.3 & -34.04 & 9 & 39.5 & 49.5 & -10.0 & -25.35 \\
\hline$-40 \%$ 이하 & 39 & 51.0 & 74.4 & -23.4 & -46.02 & 15 & 109.3 & 149.9 & -40.6 & -37.16 \\
\hline$-50 \%$ 이하 & 65 & 130.9 & 189.0 & -58.1 & -44.35 & 17 & 124.8 & 188.2 & -63.4 & -50.80 \\
\hline$-60 \%$ 이하 & 62 & 174.9 & 244.1 & -69.2 & -39.59 & 18 & 245.8 & 339.6 & -93.8 & -38.17 \\
\hline$-70 \%$ 이하 & 77 & 285.2 & 388.2 & -103.1 & -36.15 & 35 & 594.3 & 832.1 & -237.8 & -40.01 \\
\hline$-80 \%$ 이하 & 87 & 383.4 & 523.8 & -140.4 & -36.62 & 34 & 766.6 & 992.2 & -225.6 & -29.43 \\
\hline$-90 \%$ 이하 & 119 & 713.4 & 912.5 & -199.1 & -27.91 & 37 & 1316.3 & 1655.8 & -339.5 & -25.79 \\
\hline$-100 \%$ 미만 & 222 & 1598.9 & 2022.8 & -423.9 & -26.52 & 60 & 2454.7 & 3067.9 & -613.2 & -24.98 \\
\hline $100 \%$ & 514 & 3512.5 & 4474.8 & -962.3 & -27.40 & 48 & 1314.2 & 1662.1 & -347.9 & -26.48 \\
\hline 총계 & 1581 & 6990.3 & 8955.2 & -1964.9 & -28.11 & 299 & 6990.3 & 8955.2 & -1964.9 & -28.11 \\
\hline 논 면적 & \multicolumn{5}{|c|}{$400 \times 400$} & \multicolumn{5}{|c|}{$1000 \times 1000$} \\
\hline \multirow{2}{*}{ 논 비율 } & \multirow{2}{*}{$N$} & \multicolumn{2}{|c|}{ 총계 } & \multirow{2}{*}{ 차이 } & \multirow{2}{*}{ 차이\% } & \multirow{2}{*}{$N$} & \multicolumn{2}{|c|}{ 총계 } & \multirow{2}{*}{ 차이 } & \multirow{2}{*}{ 차이 $\%$} \\
\hline & & 통계청 & 피복도 & & & & 통계청 & 피복도 & & \\
\hline $0 \%$ & 218 & 32.3 & 0.0 & 32.3 & 100.00 & 12 & 0.0 & 0.0 & 0.0 & 0.00 \\
\hline$-10 \%$ 이하 & 73 & 24.8 & 14.3 & 10.5 & 42.29 & 8 & 14.1 & 7.5 & 6.6 & 46.58 \\
\hline$-20 \%$ 이하 & 51 & 29.4 & 39.1 & -9.7 & -33.03 & 6 & 10.9 & 10.5 & 0.4 & 3.57 \\
\hline$-30 \%$ 이하 & 54 & 53.8 & 72.1 & -18.3 & -34.04 & 9 & 39.5 & 49.5 & -10.0 & -25.35 \\
\hline$-40 \%$ 이하 & 39 & 51.0 & 74.4 & -23.4 & -46.02 & 15 & 109.3 & 149.9 & -40.6 & -37.16 \\
\hline$-50 \%$ 이하 & 65 & 130.9 & 189.0 & -58.1 & -44.35 & 17 & 124.8 & 188.2 & -63.4 & -50.80 \\
\hline$-60 \%$ 이하 & 62 & 174.9 & 244.1 & -69.2 & -39.59 & 18 & 245.8 & 339.6 & -93.8 & -38.17 \\
\hline$-70 \%$ 이하 & 77 & 285.2 & 388.2 & -103.1 & -36.15 & 35 & 594.3 & 832.1 & -237.8 & -40.01 \\
\hline$-80 \%$ 이하 & 87 & 383.4 & 523.8 & -140.4 & -36.62 & 34 & 766.6 & 992.2 & -225.6 & -29.43 \\
\hline$-90 \%$ 이하 & 119 & 713.4 & 912.5 & -199.1 & -27.91 & 37 & 1316.3 & 1655.8 & -339.5 & -25.79 \\
\hline$-100 \%$ 미만 & 222 & 1598.9 & 2022.8 & -423.9 & -26.52 & 60 & 2454.7 & 3067.9 & -613.2 & -24.98 \\
\hline $100 \%$ & 514 & 3512.5 & 4474.8 & -962.3 & -27.40 & 48 & 1314.2 & 1662.1 & -347.9 & -26.48 \\
\hline 총계 & 1581 & 6990.3 & 8955.2 & -1964.9 & -28.11 & 299 & 6990.3 & 8955.2 & -1964.9 & -28.11 \\
\hline
\end{tabular}

Table 3.2 를 보면, 김포지역에서는 논비율이 높고, 2 차 추출단위 크기가 클수록 피복도와 통계청의 면적 의 차이가 작아지는 경향이 나타난다.

이번에는 밭 면적에서의 차이를 살펴보자. Table 3.3 은 김포지역의 토지피복도와 원격탐사(통계청) 자 료의 밭 면적 차이를 논비율 정도에 따라 비교한 결과를 보여주는데, 뚜렷한 특징이 나타나지 않고 각 범주별로 서로 다른 양상이 나타난다.

여기서는 김포 지역의 결과만 소개했는데 8 개 지역에 대해 살펴본 결과, 두 자료 간의 밭 면적 차이는 대 체로 격자의 크기가 클수록 증가하는 양상을 띠었다. 즉, 2 차 추출단위의 크기가 커지면 두 자료의 논 면적 차이는 감소하지만 밭 면적 차이는 커지게 된다.

위에서 살펴본 $\mathrm{SSU}$ 크기에 따른 상대표준오차 비교 결과와 피복도와 영상자료의 차이 비교 결과를 요 약하면 다음과 같다. 
Table 3.3. Comparison of field acreage distribution for various SSU grid sizes (Gimpo-Si)

\begin{tabular}{|c|c|c|c|c|c|c|c|c|c|c|}
\hline 밭 면적 & \multicolumn{5}{|c|}{$100 \times 100$} & \multicolumn{5}{|c|}{$200 \times 200$} \\
\hline \multirow{2}{*}{ 밭 비율 } & \multirow{2}{*}{$N$} & \multicolumn{2}{|c|}{ 총계 } & \multirow{2}{*}{ 차이 } & \multirow{2}{*}{ 차이 $\%$} & \multirow{2}{*}{$N$} & \multicolumn{2}{|c|}{ 총계 } & \multirow{2}{*}{ 차이 } & \multirow{2}{*}{ 차이 $\%$} \\
\hline & & 통계 청 & 피복도 & & & & 통계청 & 피복도 & & \\
\hline $0 \%$ & 5690 & 937.2 & 1177.5 & -240.3 & -25.64 & 1326 & 557.7 & 730.6 & -172.9 & -31.00 \\
\hline$-10 \%$ 이하 & 414 & 118.2 & 215.8 & -97.6 & -82.51 & 193 & 162.2 & 292.7 & -130.5 & -80.41 \\
\hline$-20 \%$ 이하 & 236 & 61.8 & 108.6 & -46.8 & -75.60 & 101 & 90.0 & 133.2 & -43.2 & -47.97 \\
\hline$-30 \%$ 이하 & 188 & 55.6 & 76.4 & -20.9 & -37.58 & 122 & 102.6 & 167.0 & -64.3 & -62.69 \\
\hline$-40 \%$ 이하 & 193 & 52.4 & 67.6 & -15.2 & -28.99 & 109 & 93.7 & 117.5 & -23.8 & -25.43 \\
\hline$-50 \%$ 이하 & 218 & 51.0 & 67.3 & -16.4 & -32.11 & 111 & 81.6 & 105.5 & -23.8 & -29.19 \\
\hline$-60 \%$ 이하 & 235 & 45.6 & 60.0 & -14.4 & -31.51 & 121 & 90.7 & 104.6 & -13.9 & -15.37 \\
\hline$-70 \%$ 이하 & 249 & 41.3 & 53.3 & -12.0 & -29.02 & 126 & 80.9 & 91.1 & -10.2 & -12.66 \\
\hline$-80 \%$ 이하 & 279 & 37.7 & 41.8 & 4.1 & -10.84 & 147 & 78.7 & 68.3 & 10.4 & 13.23 \\
\hline$-90 \%$ 이하 & 321 & 42.6 & 27.4 & 15.2 & 35.76 & 233 & 95.3 & 66.5 & 28.8 & 30.22 \\
\hline$-100 \%$ 미만 & 669 & 59.8 & 14.5 & 45.3 & 75.69 & 421 & 134.1 & 33.3 & 100.7 & 75.15 \\
\hline $100 \%$ & 10709 & 611.1 & 0.0 & 611.1 & 100.00 & 2561 & 546.9 & 0.0 & 546.9 & 100.00 \\
\hline 총계 & 19401 & 2114.4 & 1910.3 & 204.2 & 9.66 & 5571 & 2114.4 & 1910.3 & 204.2 & 9.66 \\
\hline 밭 면적 & \multicolumn{5}{|c|}{$400 \times 400$} & \multicolumn{5}{|c|}{$1000 \times 1000$} \\
\hline \multirow{2}{*}{ 밭 비율 } & \multirow{2}{*}{$N$} & \multicolumn{2}{|c|}{ 총계 } & \multirow{2}{*}{ 차이 } & \multirow{2}{*}{ 차이 $\%$} & \multirow{2}{*}{$N$} & \multicolumn{2}{|c|}{ 총계 } & \multirow{2}{*}{ 차이 } & \multirow{2}{*}{ 차이 $\%$} \\
\hline & & 통계청 & 피복도 & & & & 통계청 & 피복도 & & \\
\hline $0 \%$ & 218 & 173.2 & 266.3 & -93.0 & -53.70 & 12 & 6.2 & 12.2 & -6.0 & -95.48 \\
\hline$-10 \%$ 이하 & 73 & 158.2 & 276.5 & -118.3 & -74.80 & 8 & 44.8 & 92.3 & -47.5 & -106.09 \\
\hline$-20 \%$ 이하 & 51 & 142.4 & 176.6 & -34.2 & -24.03 & 6 & 23.6 & 46.5 & -23.0 & -97.43 \\
\hline$-30 \%$ 이하 & 54 & 121.7 & 172.4 & -50.7 & -41.65 & 9 & 74.1 & 129.4 & -55.3 & -74.53 \\
\hline$-40 \%$ 이하 & 39 & 93.4 & 116.1 & -22.7 & -24.31 & 15 & 180.3 & 196.0 & -15.7 & -8.70 \\
\hline$-50 \%$ 이하 & 65 & 146.9 & 200.3 & -53.4 & -36.35 & 17 & 146.2 & 186.6 & -40.4 & -27.65 \\
\hline$-60 \%$ 이하 & 62 & 148.2 & 175.2 & 27.0 & -18.22 & 18 & 183.5 & 256.9 & -73.4 & -40.00 \\
\hline$-70 \%$ 이하 & 77 & 182.1 & 179.4 & 2.7 & 1.49 & 35 & 419.8 & 384.0 & 35.8 & 8.52 \\
\hline$-80 \%$ 이하 & 87 & 198.2 & 149.9 & 48.3 & 24.38 & 34 & 336.1 & 262.2 & 73.9 & 21.98 \\
\hline$-90 \%$ 이하 & 119 & 170.1 & 131.8 & 38.3 & 22.50 & 37 & 305.6 & 232.5 & 73.1 & 23.91 \\
\hline$-100 \%$ 미만 & 222 & 244.7 & 65.8 & 178.9 & 73.13 & 60 & 315.6 & 111.6 & 204.0 & 64.64 \\
\hline $100 \%$ & 514 & 335.3 & 0.0 & 335.3 & 100.00 & 48 & 78.6 & 0.0 & 78.6 & 100.00 \\
\hline 총계 & 1581 & 2114.4 & 1910.3 & 204.2 & 9.66 & 299 & 2114.4 & 1910.3 & 204.2 & 9.66 \\
\hline
\end{tabular}

(1) 경지 면적 추정치에 대한 상대표준오차는 격자의 크기가 작을수록 줄어드는 경향이다.

(2) 2 차 추출단위의 정사각형 격자가 커질수록 환경피복도와 원격탐사 자료의 논 면적 차이는 감소하 는 경향을 띤다.

(3) 2 차 추출단위의 정사각형 격자가 커질수록 환경피복도와 원격탐사 자료의 밭 면적 차이가 증가하 는 경향을 띤다.

특히 위의 (2)와 (3)의 결과는 서로 상충되게 나타나는데, 논의 측면에서는 $\mathrm{SSU}$ 를 크게 하는 것이 좋은 반면 밭의 측면에서는 작게 하는 것이 좋다. 이런 양상은 우리나라 피복도가 논을 중심으로 작성되는데 기인한다. 피복도에서는 규모가 작은 밭을 논으로 처리하는 경우가 많았고, 농로도 논으로 취급하는 경 우가 많은 것으로 나타났다. 
모든 면에서 다른 것을 압도할 수 있는 최선의 $\mathrm{SSU}$ 크기 결정은 어려운 형편이다. 지역에 따라서, 그리 고 관심변수에 따라서 양상은 달라지기 때문이다. 향후 전국 모든 소지역(시군)에 적용할 수 있도록 결 정해야 하므로 소지역별로 $\mathrm{SSU}$ 크기를 달리 하는 것은 효과적이지 못하다. 따라서 본 연구에서는 최종 적인 2 차 추출단위의 크기를 $200 \mathrm{~m} \times 200 \mathrm{~m}$ 로 결정하였다. 추정의 상대표준오차를 줄이는 동시에 가급 적 밭 면적의 차이를 줄이고자 하는 의도가 있기 때문이다. 그 밖에도 기존 농업면적조사의 한 조사구 크기가 약 $2 \mathrm{ha}$ 인데, 영상기반 조사로 전환할 경우 기존 조사구보다는 크게 하는 것이 바람직하다는 점 도 감안하였다.

\section{4. 맺음말}

아리랑 위성의 성공적인 발사로 우리나라 국토에 대한 해상도 높은 인공위성 영상자료의 확보가 가능해 졌다. 따라서 기존 방식의 농업면적조사를 탈피하여 몇 선진국에서 도입한 영상기반조사로의 전환을 모 색할 수 있게 되었다. 국가의 중요 통계인 농업면적통계를 기존의 방법에서 영상기반의 새로운 방법으 로 변경하는 일은 결코 단순한 일이 아니다. 세계적으로 영상기반 표본조사의 사례 자체가 아직 많이 축 적되어 있지 않은 편이다. 더욱이 나라별로 농업의 양상이 서로 달라 각 나라의 실정에 적합한 방법을 찾아야 한다.

본 논문에서는 우리나라 8 개 시범지역 영상자료를 기초로 영상기반표본설계를 위한 합리적인 1 차추출 단위와 2 차추출단위의 크기를 제시하였다. 1 차추출단위의 경우, 집락 내 동질성의 척도를 나타내는 급 내상관계수와 영상처리의 효율성 등을 감안하여 $3 \mathrm{Km} \times 3 \mathrm{Km}$ 규모로 결정하였다. 2 차추출단위의 크기 를 결정하는 데에는 모집단의 상대표준오차, 환경부 피복도 자료와 통계청의 영상처리 자료의 차이 등 을 고려하였으며, 그 결과 $200 \mathrm{~m} \times 200 \mathrm{~m}$ 의 크기로 정하였다. 1 차추출단위 $3 \mathrm{Km} \times 3 \mathrm{Km}, 2$ 차추출단위 $200 \mathrm{~m} \times 200 \mathrm{~m}$ 의 크기는 이론적인 면과 실무 측면을 모두 고려하여 나온 효과적인 방안이라고 할 것이 다. 향후에는 본 연구에서 정한 추출단위별 크기에 기초하여 우리나라 농업면적조사를 위한 본격적인 표본설계 및 조사방법 연구가 이루어질 것으로 기대한다.

\section{References}

Davies, C. (2009). Area frame design for agricultural surveys, USDA.

Galleo, F. J. and Delince, J. (2010). The European Land Use and Cover Area-Frame Statistical Survey(LUCAS), In: R. Benedetti, M. Bee, G. Espa, F. Piersimoni (eds.), Agriclutural Survey Methods, John Wiley \& Sons, Ltd.

Kish, L. (1965). Survey Sampling, Wiley.

Matern, B. (1980). Spatial Variation, Springer-Verlag.

Ministry of Environment (2002). A Study to Construct Land Cover Map using Satellite Image.

National Agricultural Products Quality (2007). Guideline of the National Cultivated Land Survey.

Statistics Korea (2008). Development of Cultivated Land Survey Method using Remote Sensing Technology. Statistics Korea (2009). ISP to Construct Cultivated Land Survey System.

Yfantis, E. A., Flatman, G. T. and Behar, J. V. (1987). Efficiency of kriging estimates for square, triangular and hexagonal grids, Mathematical Geology, 19, 183-205. 